\title{
DETERMINAN FINANCIAL DISTRESS PADA PERUSAHAAN SEKTOR PROPERTY DI BURSA EFEK INDONESIA Muni Opitalia ${ }^{1)}$ dan Mohamad Zulman ${ }^{2)}$ muniopitalia@gmail.com ${ }^{1)}$; Mohamad Zulman@gmail.com
}

\author{
Jurusan Manajemen,Universitas Muhamaddiyah, Tanggerang, Indonesia
}

\section{Info Artikel}

Sejarah Artikel: Diterima : Okt. 2019

Disetujui : Des. 2019

Dipublikasikan :

Desember 2019

Keywords: Financial

Distress; Liquidity;

Leverage; Profitability;

Activity Ratio; Sales

Growth.

\begin{abstract}
Abstrak
Tujuan dari penelitian ini untuk mengetahui pengaruh Likuiditas, Leverage, Profitabilitas, Sales Growth, dan Rasio Aktivitas Terhadap Financial Distress pada Sub Sektor Perusahaan Property, Real Estate, dan Kontruksi Bangunan yang Terdaftar Di Bursa Efek Indonesia Periode 2015-2018.Populasi penelitian ini meliputi seluruh perusahaan sub sektor property, real estate, dan kontruksi bangunan yang terdaftar di Bursa Efek Indonesia (BEI) periode 2015-2018. Teknik pengambilan sampel menggunakan teknik purposive sampling. Sehingga diperoleh sampel sebanyak 10 perusahaan Berdasarkan kriteria yang telah ditetapkan. Jenis data yang digunakan adalah data sekunder yang diperoleh dari situs Bursa Efek Indonesia.Berdasarkan hasil penelitian variabel rasio likuiditas, rasio leverage, rasio profitabilitas, rasio sales growth dan rasio aktivitas secara simultan berpengaruh signifikan terhadap financial distress. Sedangkan secara parsial rasio leverage berpengaruh negatif signifikan terhadap financial distress. rasio profitabilitas memiliki pengaruh positif terhadap financial distress dan rasio likuiditas, rasio sales growth dan rasio aktivitas tidak memiliki pengaruh terhadap financial distress.
\end{abstract}

\section{DETERMINANTS OF FINANCIAL DISTRESS IN PROPERTY SECTOR COMPANIES IN INDONESIA STOCK EXCHANGE}

\begin{abstract}
The purpose of this study was to determine the effect of Liquidity, Leverage, Profitability, Sales Growth, and Activity Ratios of Financial Distress in the Property, Real Estate and Building Construction Sub-Sector Companies Listed on the Indonesia Stock Exchange in the Period of 2015-2018. The population of this study includes all property, real estate, and construction subsector companies listed on the Indonesia Stock Exchange (IDX) for the 2015-2018 period. The sampling technique uses purposive sampling technique. In order to obtain a sample of 10 companies based on predetermined criteria. The type of data used is secondary data obtained from the Indonesia Stock Exchange website.Based on the results of the study liquidity ratio variables, leverage ratios, profitability ratios, sales growth ratios and activity ratios simultaneously have a significant effect on financial distress. While partially the leverage ratio has a significant negative effect on financial distress. profitability ratios have a positive effect on financial distress and liquidity ratios, sales growth ratios and activity ratios have no influence on financial distress.
\end{abstract}

\footnotetext{
Alamat korespondensi :

Jl Soekarno-Hatta Semarang

E-mail: muniopitalia@gmail.com
}

ISSN

1979-48oo (cetak)

2580-8451 (online) 


\section{PENDAHULUAN}

Setiap perusahaan memiliki tujuan untuk memperoleh keuntungan yang besar secara terus menerus, dimana keuntungan tersebut akan digunakan untuk membiayai kegiatan operasional perusahaan dan aktivitas lainnya dalam rangka mempertahankan kelangsungan hidup usahanya. Akan tetapi, pada kenyataannya tidak semua perusahaan dapat mewujudkan hal tersebut, dikarenakan masih banyaknya perusahaan yang mengalami kebangkrutan sebagai akibat dari adanya permasalahan financial distress yang tidak dapat diatasi dengan baik. Financial distress merupakan situasi ketika perusahaan tidak memiliki aset yang cukup untuk melunasi kewajibannya, baik kewajiban jangka pendek maupun kewajiban jangka panjangnya (Madhushani dan Kawshala, 2018). Financial distress dapat terjadi pada seluruh jenis perusahaan, walaupun perusahaan yang bersangkutan merupakan perusahaan besar dan berkategori sehat pun akan tetap dapat mengalami kesulitan dalam pemenuhan dana untuk kegiatan operasional perusahaan akibat adanya krisis ekonomi. Saat ini perekonomian di Indonesia selalu mengalami perkembangan dari tahun ke tahun. Menteri Keuangan Sri Mulyani menilai kondisi dan situasi ekonomi di Indonesia telah berkembang setelah 20 tahun reformasi sehingga berbeda dengan kondisi sebelum krisis moneter 1997-1998 (Investor Daily, 22/05/2018). Berdasarkan data Bursa Efek Indonesia, indeks sektor properti, real estate, dan kontruksi bangunan sepanjang 2017 turun 4,31\% disaat IHSG justru melonjak 19,99\%. Pada tahun 2018 indeks sektor properti, real estate, dan kontruksi bangunan masih belum membaik (Bisnis.com, 09/01/2018). Pergerakan saham-saham sektor properti masih melemah dari data Bursa Efek Indonesia (BEI), indeks sektor properti, real estate, dan kontruksi bangunan turun sebesar 8,37\% (Kontan.co.id, 14/05/2018). Kinerja sektor tersebut ternyata tidak terbukti membaik meskipun suku bunga BI mengalami penurunan (market.bisnis.com). Melihat dari situasi tersebut banyak para ekonom, analis keuangan dan para peneliti menyadari betapa pentingnya memahami alasan dibalik runtuhnya perusahaan. Mengetahui alasan ini mungkin dapat menghambat perusahaan dari kondisi financial distress perusahaan dan tindakan dini dapat diambil sebagai tindakan pencegahan (Andreica, et al 2009 dalam Nurcahyono, dan Sudharma, 2014). Dalam menilai kondisi keuangan suatu organisasi atau perusahaan guna mengetahui terjadinya suatu kondisi financial distress atau non financial distress pada suatu perusahaan yaitu dengan menggunakan rasio likuiditas, rasio leverage, rasio pertumbuhan, rasio profitabilitas dan rasio aktivitas.

Likuiditas menunjukkan bahwa dengan tingkat aktiva yang dimiliki perusahaan maka perusahaan tersebut mampu untuk membayar hutang lancar, karena setiap perusahaan yang mampu untuk membayar hutang lancar dengan baik, maka semakin kecil kemungkinan perusahaan akan mengalami kondisi financial distress (Rismawanti, Sukarmanto, dan Nurhayati, 2017). Dalam hasil penelitian terdahulu oleh Haq, Arfan, Siswar (2013), Nurhidayah dan Fitriyatur Rizqiyah (2017)likuiditas berpengaruh positif terhadap financial distress. Hal ini berbeda dengan penelitian menurut Widhiari dan Merkusiwati (2015) yaitu likuiditas memiliki pengaruh negatif terhadap financial distress sedangkan menurut Simanjuntak, Titik, Aminah (2017), Nurcahyono, Sudharma (2014) menyatakan bahwa likuiditas tidak berpengaruh terhadap financial distress. Leverage menggambarkan bahwa semakin besar rasio ini semakin besar jumlah aktiva perusahaan yang dibiayai oleh hutang, sehingga probabilitas perusahaan terhadap kondisi financial distress akan semakin tinggi. Rasio yang tinggi menunjukkan perusahaan menggunakan leverage keuangan yang tinggi (Saleh dan Sudiyatno, 2013). Dalam hasil penelitian Rohmadini, Saifi, dan Darmawan (2017), Elliu (2014) leverage berpengaruh negatif terhadap financial distress. Namun berbeda dengan penelitian Widhiari, Merkusiwati (2015) yang membuktikan bahwa leverage tidak berpengaruh terhadap financial distress sedangkan Simanjuntak, Titik, Aminah (2017), Rismawanti, Sukarmanto, Nurhayati (2017) menunjukkan bahwa leverage memiliki 
pengaruh positif terhadap financial distress. Profitabilitas juga merupakan suatu hal yang sangat penting bagi investor dalam mengambil keputusan investasi Salah satu kegunaan dari pengukuran profitabilitas yaitu untuk mengukur kemampuan perusahaan dalam menghasilkan laba bersih dengan menggunakan total aset yang dimiliki perusahaan (Putra dan Lestari, 2016). Apabila hasil pengukuran dari profitabilitas itu tinggi maka menunjukkan semakin baik juga kondisi perusahaan dalam memperoleh keuntungan. Dengan begitu, hal tersebut juga akan meminimalkan terjadinya kondisi financial distress (Sugiono dan Untung, 2016). Profitabilitas berpengaruh positif dan signifikan terhadap financial distress . Hasil penelitian Hapsari (2012) rasio profitabilitas mempengaruhi kondisi financial distress, Mas'ud dan Srengga (2011) rasio profitabilitas berpengaruh signifikan terhadap financial distress. Lillananda Putri Mayangsari (2015) semakin besar profitabilitas suatu perusahaan semakin mengurangi kondisi financial distress perusahaan tersebut dan rasio yang paling dominan dalam memprediksi kondisi financial distress adalah rasio profitabilitas. Dengan demikian rasio Profitabilitas berpengaruh negatif terhadap kondisi financial distress. Sales growth mencerminkan persentasi kenaikan penjualan tahun ini yang dibandingkan dengan tahun sebelumnya, semakin tinggi sales growth yang terjadi pada suatu perusahaan maka akan semakin baik karena perusahaan tersebut berhasil dalam menjalankan strategi pemasaran dan penjualan produk dan begitupun sebaliknya jika semakin rendah sales growth maka akan semakin besar pula kemungkinan financial distress (Rismawanti, Sukarmanto, dan Nurhayati, 2017). Dari penelitian terdahulu oleh Simanjuntak, Titik, dan Aminah (2017) sales growth tidak berpengaruh terhadap financial distress. Tetapi menurut Widhiari, Merkusiwati (2015) sales growth berpengaruh negatif terhadap financial distress. hasil penelitian dari Radiansyah (2013) serta Martha (2013) yang menunjukkan bahwa rasio sales growth berpengaruh terhadap financial distress. Rasio aktivitas menunjukan perputaran total aset yang diukur dari volume penjualan dengan kata lain seberapa jauh kemampuan semua aset dapat menciptakan penjualan. Apabila dalam sebuah perusahaan tidak dapat meningkatkan penjualan, maka perusahaan tersebut lama-kelamaan akan mengalami penurunan laba perusahaan, dan akhirnya perusahaan akan mengalami financial distress.. Widhiari dan Merkusiwati (2015) yang menyatakan bahwa rasio aktivitas dengan proksi total asset turnover berpengaruh negatif terhadap financial distress. Berdasarkan analisis yang telah dilakukan dalam penelitian ini, bahwa total Asset turnover (TATO) berpengaruh positif dan signifikan terhadap financial distress. Berdasarkan latar belakang di atas maka penelitian ini akan menguji pengaruh Likuiditas, profitabilitas, sales growth dan rario aktivitas terhadap Financial Distress.

\section{TELAAH PUSTAKA \\ Signaling Theory}

Signaling theory yaitu teori yang melihat tanda-tanda tentang kondisi yang menggambarkan suatu perusahaan. Teori ini juga membahas tentang ketidakstabilan kenaikan ataupun penururan harga di pasar, sehingga dapat berpengaruh terhadap keputusan investor (Fahmi, 2012).Menurut Khairudin \& Wandita (2017) Teori sinyal merupakan sinyal-sinyal informasi yang dibutuhkan oleh investor untuk mempertimbangkan dan menentukan apakah para investor akan menanamkan sahamya atau tidak pada perusahaan yang bersangkutan. Teori sinyal menekankan pentingnya informasi yang diterbitkan perusahaan terhadap keputusan investor sebagai pihak eksternal. Investor selalu membutuhan informasi yang lengkap, relavan, akurat dan tepat waktu untuk menganalisis dalam mengambil keputusan. Menurut Chusnitah dan Retnani (2017) Informasi tersebut merupakan hal yang sangat penting bagi investor dan pelaku bisnis karena menyajikan catatan, keterangan, atau gambaran mengenai kelangsungan hidup perusahaan. 


\section{Laporan keuangan PSAK No 1}

Didalam PSAK no.1 disebutkan tentang penyajian laporan keuangan yang terdiri dari strukur laporan keuangan, dan persyaratan isi laporan keuangan. Tujuannya untuk umum dan tidak berlaku bagi laporan keuangan entitas syariah. Hal ini dilakukan supaya laporan keuangan bisa tersusun dengan jelas dan terstruktur rapi,sehingga standar akuntansi keuangan menyebutkan persyaratan dan bagaimana penyusunan yang benar.

Adapun pengertian laporan keuangan yang dikemukakan PSAK No. 1 dalam standar Akuntansi Keuangan tahun 2017 adalah sebagai berikut:"Laporan keuangan adalah suatu penyajian terstruktuir dari posisi keuangan dan kinerja keuangan suatu entitas. Tujuan laporan keuangan adalah menyediakan informasi yang yang menyangkut posisi keuangan, kimerja serta pertumbuhan posisi keuangan suatu entitas yang bermanfaat bagi sebagian besar pengguna laporan keuangan dalam pengambilan keputuisan ekonomik"

Komponen laporan keuangan yang lengkap menurut pernyataan standar akuntansi keuangan No.1 tahun 2017 terdiri dari komponen-komponen berikut:

1. Laporan posisi keuangan akhir periode

2. Laporan laba rugi dan kompherensif lain

3. Laporan Perubahan ekuitas

4. Laporan Arus

\section{Financial Distress}

Kondisi kesulitan keuangan atau financial distress adalah kondisi yang bermula dari tidak tertib atau kacaunya pengelolaan keuangan pada suatu perusahaan. Financial distress ini dimulai dari tekanan likuiditas yang semakin lama semakin berat, kemudian berlanjut pada kondisi menurunnya nilai aset, sehingga tidak mampu membayar berbagai kewajiban keuangannya (Noor, 2014). Terjadinya ancaman kebangkrutan bukan hanya kebangkrutan itu sendiri tetapi juga masalah yang ditimbulkannya seperti karyawan penting keluar, pemasok menolak memberikan kredit, pelanggan mencari perusahaan lain yang lebih stabil, serta pemberi pinjaman memberi suku bunga yang lebih tinggi dan menetapkan syarat-syarat yang lebih ketat yang tertuang didalam kontrak pinjaman (Nariman, 2016).penelitian ini diukur dengan model Springate. Persamaan yang diperkenalkan oleh Springate ini ialah.

$\mathrm{Z}=1.03 \mathrm{~A}+3.07 \mathrm{~B}+0.66 \mathrm{C}+0.4 \mathrm{D}$

Keterangan:

A = Working capital / Total assets

$\mathrm{B}=$ Net profit before interest and taxes / Total assets

$\mathrm{C}=$ Net profit before taxes / Current liabilities

$\mathrm{D}=$ Sales / Total assets

Kriteria untuk persamaan model Springate ini adalah jika nilai $\mathrm{Z}<0,862$ maka perusahaan termasuk perusahaan bangkrut dan jika nilai $\mathrm{Z}>0,862$ maka perusahaan dikategorikan termasuk perusahaan sehat (Nur Rhomadhona, 2013).

\section{Likuiditas}

Gitman dan Zutter (2015) menjelaskan likuiditas sebagai pengukur kemampuan untuk memenuhi kewajiban jangka pendeknya yang jatuh tempo. Likuiditas juga lebih mengarah kepada neraca suatu perusahaan yang dimana memberikan informasi perusahaan mengenai kemudahan dalam membayar hutangnya.

$$
\mathrm{CR}=\frac{\text { Current Asset }}{\text { Current Liability }}
$$

\section{Leverage}


Leverage yaitu rasio yang digunakan untuk mengetahui kemampuan perusahaan dalam mambayar kewajiban jika perusahaan tersebut dilikuidasi (Sumarsan, 2013).Sari dan Priyadi (2016) rasio solvabilitas atau leverage merupakan suatu alat penting dalam pengukuran efektifitas penggunaan hutang perusahaan. Sedangkan menurut Ernitasianturi (2015) rasio solvabilitas atau leverage merupakan rasio untuk mengukur sejauh mana perusahaan dibiayai dengan hutang. Berdasarkan definisi tersebut dapat diketahui bahwa Solvabilitas merupakan rasio yang digunakan untuk mengukur beban hutang yang ditanggung perusahaan dalam memenuhi aktivitas perusahaan.

\section{Profitabilitas}

$$
\text { DAR }=\frac{\text { Total Liabilities }}{\text { Total Asset }}
$$

Profitablitas merupakan kemampuan perusahaan menghasilkan laba. Dimana laba merupakan salah satu indikator seberapa baik kinerja perusahaan. Profitabilitas mencakup seluruh pendapatan dan biaya yang dikeluarkan oleh perusahaan sebagai penggunaan aktiva dan pasiva dalam suatu periode. Investor menggunakan profitabilitas untuk memprediksi seberapa besar penggunaan nilai atas saham yang dimiliki. Dalam penelitian ini pengukuran terhadap profitabilitas diukur dengan membandingkan laba setelah pajak dengan total asset.

\section{Sales Growth}

$$
(\mathrm{ROA})=\frac{\text { Laba bersih }}{\text { Total Asset }} \times 100 \%
$$

Kasmir (2016: 114) mendefinikan bahwa sales growth yaitu rasio yang menggambarkan kemampuan perusahaan dalam mempertahankan posisi ekonominya di tengah pertumbuhan perekonomian dan sektor usahanya. Sales growth mencerminkan persentasi kenaikan penjualan tahun ini yang dibandingkan dengan tahun sebelumnya, semakin tinggi sales growth maka akan semakin baik karena perusahaan tersebut berhasil dalam menjalankan strategi pemasaran dan penjualan produk dan begitupun sebaliknya jika semakin rendah sales growth maka akan semakin besar pula kemungkinan financial distress (Rismawanti, Sukarmanto, dan Nurhayati, 2017).

$$
\mathrm{SG}=\frac{\text { Sales periode } t-\text { sales periode }(t-1)}{\text { sales periode }(t-1)}
$$

\section{Rasio Aktivitas}

Rasio aktivitas menurut Kasmir (2014:172) merupakan rasio yang digunakan untuk mengukur efektivitas perusahaan dalam menggunakan aktiva yang dimilikinya atau dapat pula dikatakan rasio ini digunakan untuk mengukur tingkat efisiensi (efektivitas) pemanfaatan sumber daya perusahaan.

\section{Kerangka Konseptual}

$$
(\mathrm{TATO})=\frac{\text { Penjualan }}{\text { Total Asset }} \times 100 \%
$$

Likuiditas menunjukkan bahwa dengan tingkat aktiva yang dimiliki perusahaan maka perusahaan tersebut mampu untuk membayar hutang lancar, karena setiap perusahaan yang mampu untuk membayar hutang lancar dengan baik, maka semakin kecil kemungkinan perusahaan akan mengalami kondisi financial distress (Rismawanti, Sukarmanto, dan Nurhayati, 2017).

Leverage menggambarkan bahwa semakin besar rasio ini semakin besar jumlah aktiva perusahaan yang dibiayai oleh hutang, sehingga probabilitas perusahaan terhadap kondisi financial distress akan semakin tinggi. Rasio yang tinggi menunjukkan perusahaan menggunakan leverage keuangan yang tinggi (Saleh dan Sudiyatno, 2013). 
Profitabilitas menunjukkan kemampuan perusahaan untuk menghasilkan laba ditahan dari total aktiva perusahaan. Jika rasio profitabilitas naik maka akan meningkat dan berpengaruh terhadap financial distress karena laba ditahan memiliki andil dalam mempertahankan perusahaan dalam menjalankan operasinya karena laba ditahan digunakan untuk modal operasi perusahaan.

Sales growth dapat menjadi ukuran dari keberhasilan investasi yang terjadi pada periode lalu, sehingga dapat dijadikan prediksi pertumbuhan perusahaan di masa yang akan datang. Sales growth dapat mempengaruhi keuntungan yang dimiliki perusahaan di masa yang akan datang. Sales growth yang tinggi dapat meningkatkan pendapatan perusahaan dari hasil penjualan yang terjadi selama periode tertentu pada perusahaan tersebut. Sales growth menunjukkan angka yang rendah dapat menyebabkan perusahaan mengalami kondisi financial distress karena penjualan yang turun dari periode lalu sehingga dapat mempengaruhi aset, laba, dan hutang perusahaan.

Rasio aktivitas, merupakan rasio yang digunakan untuk mengukur tingkat efisiensi atas pemanfaatan sumber daya yang dimiliki perusahaan, atau untuk menilai kemampuan perusahaan dalam menjalankan aktivitasnya sehari-hari. Jika pelaku kegiatan pengelolaan perusahaan tidak bisa memaksimalkan penggunaan asset perusahaan, penjualan perusahaan juga tidak bisa maksimal, sehingga akan mendekatkan suatu perusahaan terhadap ancaman financial distress.

Berikut kerangka konseptual untuk lebih memudahkan pemahaman dalam penelitian ini:

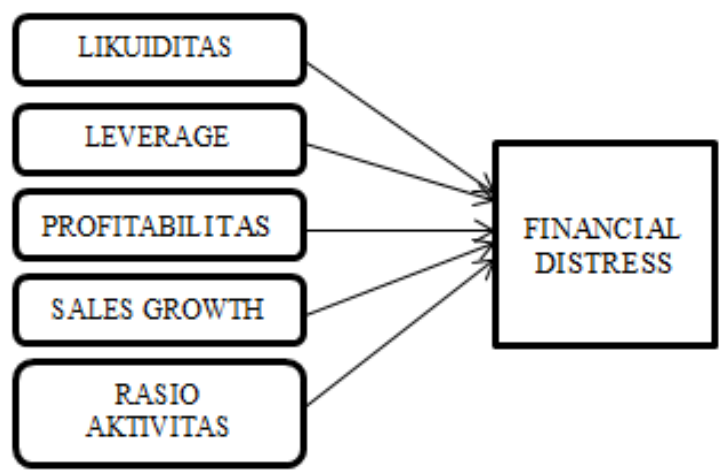

\section{Gambar 1 Kerangka Konseptual Penelitian}

\section{METODE}

Jenis Data

Penelitian ini menggunakan Data kuantitatif. . Data kuantitatif yaitu data yang berupa angka yang berkaitan dengan masalah yang akan di teliti. Data penelitian ini didapat dari laporan keuangan yang telah dipublikasikan oleh perusahaan. Laporan keuangan yang digunakan adalah laporan keuangan yang telah diaudit oleh auditor independen.

\section{Metode Pengumpulan Data}

Penelitian ini menggunakan metode purposive sampling sebagai metode yang digunakan. Dalam metode Purposinve Sampling pemilihan anggota sampel berdasarkan kriteria-kriteria tertentu. Sampel yang digunakan dalam penelitian ini adalah perusahaan sub sector property, real estate dan kontruksi bangunan yang terdaftar di BEI periode 2015-2018 yang memiliki kriteria sebagai berikut; (1) Perusahaan jasa sub sektor property, real estate, dan kontruksi bangunan go public yang terdaftar dan konsisten di Bursa Efek Indonesia periode 2015-2018; (2) Perusahaan jasa sub sektor property, real estate dan kontruksi bangunan yang mempublikasikan laporan keuangan periode 2015- 
2018; (3) Perusahaan jasa sub sektor property, real estate dan kontruksi bangunan yang memperoleh keuntungan selama periode 2015-2018; (4) Perusahaan jasa sub sektor property, real estate dan kontruksi bangunan yang menggunakan mata uang rupiah.

Berdasarkan dari kriteria pengambilan sampel dapat diketahui bahwa yang memenuhi kriteria sampel penelitian adalah 10 perusahaan selama 4 tahun sehingga jumlah observasi sebanyak 40 sampel.

\section{Teknik Analisis Data}

\section{Analisis Regresi data Panel}

Metode analisis data yang digunakan dalam penelitian adalah analisis regresi data panel. Analisis regresi data panel adalah gabungan antara data cross section dan data time series, dimana unit cross section yang sama diukur pada waktu yang berbeda. Maka dengan kata lain, data panel merupakan data dari beberapa individu (sampel) yang diamati dalam beberapa kurun waktu tertentu. (Eksandy dan Heriyanto, 2017). Bentuk umum persamaan regresi data panel yang digunakan dalam penelitian ini adalah sebagai berikut: $\mathrm{Y}=\alpha+\beta 1 \mathrm{X} 1+\beta 2 \mathrm{X} 2+\beta 3 \mathrm{X} 3 \quad+\beta 4 \mathrm{X} 4+\beta \mathrm{X} 5+e$.

\section{HASIL DAN PEMBAHASAN}

\section{Analisis Statistik Deskriptif}

\section{Tabel 1}

Hasil Analisis Diskriptif

\begin{tabular}{|c|c|c|c|c|c|c|}
\hline & FD & $C R$ & DER & ROA & GROWTH & TATO \\
\hline Mean & 0.617563 & 1.292010 & 0.555506 & 0.030721 & 0.345944 & 0.023972 \\
\hline Median & 0.597319 & 1.281637 & 0.535167 & 0.029249 & 0.134100 & 0.006243 \\
\hline Maximum & 1.536740 & 2.598504 & 0.840339 & 0.140244 & 1.907015 & 0.259553 \\
\hline Minimum & 0.125306 & 0.393509 & 0.238231 & 0.001746 & 0.004319 & 0.000381 \\
\hline Sto. Dev. & 0.24224 & 0.515990 & 0.151433 & 0.024531 & 0.40068 & 0.059587 \\
\hline Obsenations & 40 & 40 & 40 & 40 & 40 & 40 \\
\hline
\end{tabular}

Sumber : data diolah

Dari Tabel 1 diketahui bahwa jumlah pengamatan (N) Pada perusahaan sub sektor property, real estate dan kontruksi bangunan yang terdaftar di Bursa Efek Indonesia periode 2015-2018 adalah sebanyak 40 data. Maka dapat diketahui Financial Distress yang diukur dengan model Springate memiliki nilai minimal 0.125306 sampai nilai maksimal 1.536740 dengan rata-rata 0.617563 dan standar deviasi 0.244224 .

Variabel CR merupakan proksi dari faktor likuiditas Berdasarkan hasil perhitungan, deskripsi statistik variabel CR pada 2015-2018 ditunjukkan pada tabel berikut bervariasi antara nilai minimal 0.393509 sampai nilai maksimal 2.598504 dengan rata-rata 1.292010 dan standar deviasi 0.515990 . Semakin rendah rasio ini, semakin rendah juga kemampuan likuiditas perusahaan sub sektor property, real estate dan kontruksi bangunan yang terdaftar di BEI tahun 2015-2018 bersangkutan untuk membiayai hutang jangka pendeknya, sehingga kemungkinan suatu perusahaan dalam kondisi financial distress akan semakin besar.

DER merupakan proksi dari faktor leverage Berdasarkan hasil perhitungan, deskripsi statistik variabel DER pada 2015-2018 ditunjukkan pada tabel berikut bervariasi antara nilai minimal 0.238231 sampai nilai maksimal 0.840339 dengan rata-rata 0.555506 dan standar deviasi 0.151433. Semakin tinggi rasio ini menunjukkan semakin rendahnya kemampuan leverage perusahaan sub sektor property, 
real estate dan kontruksi bangunan yang terdaftar di BEI tahun 2015-2018 yang bersangkutan sehingga kemungkinan suatu perusahaan dalam kondisi financial distress akan semakin tinggi.

ROA merupakan proksi dari factor profitabilitas Berdasarkan hasil perhitungan, deskripsi statistik variabel ROA pada 2015-2018 ditunjukkan pada tabel berikut bervariasi antara nilai minimal 0.001746 sampai nilai maksimal 0.140244 dengan rata-rata 0.030721 dan standar deviasi 0.024531. Semakin tinggi rasio ini menunjukkan semakin Tinggi kemampuan profitabilitas perusahaan sub sektor property, real estate dan kontruksi bangunan yang terdaftar di BEI tahun 2015-2018 yang bersangkutan sehingga kemungkinan suatu perusahaan tidak akan mengalami financial distress.

GROWTH merupakan proksi dari factor sales growth Berdasarkan hasil perhitungan, deskripsi statistik variabel GROWTH pada 2015-2018 ditunjukkan pada tabel berikut bervariasi antara nilai minimal 0.004319 sampai nilai maksimal 1.907015 dengan rata-rata 0.345944 dan standar deviasi 0.440668 . Semakin rendah rasio ini menunjukkan semakin rendahnya kemampuan sales growth perusahaan sub sektor property, real estate dan kontruksi bangunan yang terdaftar di BEI tahun 2015-2018 yang bersangkutan sehingga kemungkinan suatu perusahaan dalam kondisi financial distress.

TATO merupakan proksi dari factor rasio aktivitas Berdasarkan hasil perhitungan, deskripsi statistik variabel TATO pada 2015-2018 ditunjukkan pada tabel berikut bervariasi antara nilai minimal 0.000381 sampai nilai maksimal 0.259553 dengan ratarata 0.023972 dan standar deviasi 0.059587 .

2. Uji Berpasangan Dua Model

a. Uji Chow (Common Effect vs Fixed Effect)

Tabel 2

Hasil Pengujian Uji Chow

RedundantFixed Effects Tests

Equation: EQ01

Test cross-sectionfixed effects

\begin{tabular}{lrrr}
\hline \hline Effects Test & Statistic & d.f. & Prob. \\
\hline \hline Cross-section F & 2.507020 & $(9,25)$ & 0.0336 \\
Cross-section Chi-square & 25.727327 & 9 & 0.0023 \\
\hline \hline
\end{tabular}

Sumber: data diolah

Berdasarkan hasil perhitungan diatas nilai probabilitas croos-section $\mathrm{f}$ dan crosssection chi-square $<\alpha(0.05)$, maka dapat disimpulkan bahwa fixed effect model (FEM) lebih layak digunakan dibandingkan common effect model (CEM).

b. Uji Hausman (Fixed Effect vs Random Effect) 
Tabel 3

Hasil Uji Hausman

\begin{tabular}{l} 
Correlated Random Effects - Hausman Test \\
Equation: EQ01 \\
Test cross-sectionrandom effects \\
\hline \hline \\
Test Summary
\end{tabular} \begin{tabular}{llll} 
Chi-Sq. & & & \\
\hline \hline Cross-section random & 15.137840 & 5 & 0.0098 \\
\hline \hline
\end{tabular}

Sumber: data diolah

Berdasarkan hasil perhitungan diatas nilai probabilitas croos-section random $>\alpha$ (0.05), maka dapat disimpulkan bahwa fixed effect model (FEM) lebih layak digunakan dibandingkan random effect model (REM).

\section{c. Uji Langrage Multiplier (Common Effect vs Random Effect)}

\section{Tabel 4}

Hasil Uji Langage Multiplier

Lagrange Multiplier Tests for Random Effects
$\begin{aligned} & \text { Null hypotheses: No effects } \\
& \text { Alternative hypotheses: Two-sided (Breusch-Pagan) and one-sided } \\
& \text { (all others) alternatives }\end{aligned}$
\begin{tabular}{lccc}
\multicolumn{4}{c}{ Test Hypothesis } \\
\hline \hline & \multicolumn{4}{c}{ Cross-section } & Time & Both \\
\hline \hline Breusch-Pagan & 0.477669 & 0.916473 & 1.394142 \\
& $(0.4895)$ & $(0.3384)$ & $(0.2377)$
\end{tabular}

Sumber : data diolah

Berdasarkan hasil perhitungan diatas nilai probabilitas croos-section Breauschpagan $<\alpha(0.05)$ maka disimpulkan bahwa common effect model (CEM) lebih banyak digunakan dibandingkan random effect model (REM).

\section{Uji Asumsi Klasik}

Uji asumsi klasik bertujuan untuk mengetahui dan menguji kelayakan atas model regresi yang digunakan untuk penelitian ini. Pengujian ini juga dimaksudkan untuk memastikan, bahwa di dalam model regresi yang digunakan tidak terdapat autokorelasi, multikolinearitas, dan heteroskedastisitas. Adapun masing masing pengujian yang akan dijelaskan dibawah ini.

\section{a. Uji Multikolineritas}

Uji multikolinearitas bertujuan untuk menguji apakah dalam model regresi ditemukan adanya korelasi yang tinggi atau sempurna antar variabel independen (Ghozali dan Ratmono, 2013:77). Hasil uji multikolinearitas ditampilkan pada Tabel seperti dibawah ini. 
Tabel 5

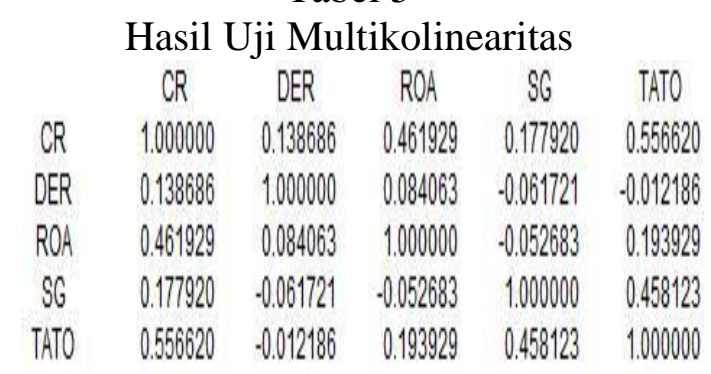

Sumber : Hasil output eviews

Berdasarkan tabel diatas, dapat dilihat bahwa nilai centered VIF dari seluruh variabel yaitu Likuiditas(CR), Leverage(DER), Profitabilitas (ROA), Sales Growth(SG), dan Rasio Aktivitas(TATO) lebih kecil dari 10. Sehingga dapat disimpulkan, bahwa tidak terdapat multikolinearitas antar variabel independen.

\section{b. Hasil Uji Heteroskedasitas}

Uji heteroskedastisitas untuk mengetahui apakah dalam model regresi terjadi ketidak samaan antar variance dari residual satu ke pengamatan lain. Hasil uji heteroskedastisitas ditampilkan dalam Tabel seperti dibawah ini :

\section{Tabel 6}

Hasil Uji Heteroskedastisitas

\begin{tabular}{|c|c|c|c|}
\hline \multicolumn{4}{|c|}{$\begin{array}{l}\text { Residual Cross-Section Dependence Test } \\
\text { Null hypothesis: No cross-section dependence (correlation) in residuals } \\
\text { Equation: EQ01 } \\
\text { Periods included: } 4 \\
\text { Cross-sections included: } 10 \\
\text { Total panel observations: } 40 \\
\text { Note: non-zero cross-section means detected in data } \\
\text { Cross-section means were removed during computation of correlations }\end{array}$} \\
\hline Test & Statistic & d.f. & Prob. \\
\hline Breusch-Pagan LM & 50.46691 & 45 & 0.2663 \\
\hline Ressaran scaled LM & $\begin{array}{r}-0.477829 \\
-0994896\end{array}$ & & $\begin{array}{l}0.6328 \\
0.3198\end{array}$ \\
\hline
\end{tabular}

Sumber: Hasil Olah Data Eviews

Pengujian kedua yaitu heteroskedastisitas dengan tujuan untuk mengetahui pengaruh antar variabel bebas dengan absolute residual. Berdasarkan Tabel 05 terlihat bahwa nilai signifikansi pada variabel pesaran scaled LM,likuiditas, sales growth, dan rasio aktivitas $>0,05$ Jadi dapat disimpulkan bahwa tidak terjadi gejala heteroskedastisitas karena tidak terdapat pengaruh antar variabel bebas dengan absolute residual.

\section{Kesimpulan Model}

Berdasarkan pengujian terhadap ketiga model regresi data panel, dapat disimpulkan bahwa model Fixed Cost dalam regresi data panel digunakan lebih lanjut dalam mengestimasi pengaruh Likuiditas, Leverage, Profitabilitas, Sales growth, dan Rasio Aktivitas terhadap Financial Distress. pada perusahaan jasa sub sektor property, real estate, dan kontruksi bangunan yang terdaftar di bursa efek Indonesia pada tahun 20152018. 
Uji Kelayakan Model ( Uji F)

\section{Tabel 7 \\ Hasil Uji Kelayakan Model}

\begin{tabular}{|c|c|c|c|c|}
\hline $\begin{array}{l}\text { Dependent Variable: } \\
\text { Method: Panel Leas } \\
\text { Date: } 11 / 11 / 19 \text { Tim } \\
\text { Sample: } 20152018 \\
\text { Periods included: } 4 \\
\text { Cross-sections inclu } \\
\text { Total panel (balance }\end{array}$ & $\begin{array}{l}\text { Dervations: } 40 \\
\text { Do }\end{array}$ & & & \\
\hline Variable & Coefficient & Std. Error & t-Statistic & Prob. \\
\hline c & 0.557880 & 0.209885 & 2.658023 & 0.0135 \\
\hline $\mathrm{CR}$ & 0.125581 & 0.080326 & 1.563402 & 0.1305 \\
\hline DER & -0.580292 & 0.269186 & -2.155731 & 0.0409 \\
\hline ROA & 6.201397 & 0.691076 & 8.973539 & 0.0000 \\
\hline SG & -0.022357 & 0.055925 & -0.399757 & 0.6927 \\
\hline TATO & 1.543795 & 1.085237 & 1.422542 & 0.1672 \\
\hline \multicolumn{5}{|c|}{ Effects Specification } \\
\hline \multicolumn{5}{|c|}{ Cross-section fixed (dummy variables) } \\
\hline R-squared & 0.924739 & \multirow{2}{*}{\multicolumn{2}{|c|}{$\begin{array}{l}\text { Mean dependentyar } \\
\text { S.D. dependentyar }\end{array}$}} & 0.617563 \\
\hline Adjusted R-squared & 0.882593 & & & 0.244224 \\
\hline S.E. of regression & 0.083682 & \multicolumn{2}{|c|}{$\begin{array}{l}\text { S.D. dependent var } \\
\text { Akaike info criterion }\end{array}$} & -1.843581 \\
\hline Sum squared resid & 0.175068 & \multirow{2}{*}{\multicolumn{2}{|c|}{ Hannan-Quinn criter. }} & -1.210251 \\
\hline Log likelihood & 51.87161 & & & -1.614588 \\
\hline F-statistic & 21.94134 & \multicolumn{2}{|c|}{ Durbin-Wats on stat } & 3.342599 \\
\hline Rrob(F-statistic) & 0.000000 & & & \\
\hline
\end{tabular}

Sumber: Hasil Olah Data Eviews

Dalam Output diatas menunjukan bahwa nilai F-Statistic sebesar 21.94134 sedangkan $\mathrm{F}$ table dengan tingkat $\alpha=5 \%$, df1 (k-1) $=5$ dan df2 $(\mathrm{n}-\mathrm{k})=35$ maka nilai $\mathrm{F}$ tabel sebesar 2,49 Dengan demikian F-Statistic (21.94134)> F Tabel $(2,49)$ dan nilai Prob(F-Statistic) $0.000000>0.05$ Maka dapat disimpulkan bahwa Ha Diterima hal ini dapat disimpukan bahwa variabel-variabel independen memiliki pengaruh secara bersama-sama terhadap Financial Distress.

\section{Koefisien Determinasi}

Dari hasil perhitungan tersebut diperoleh besarnya pengaruh variabel independen terhadap variabel dependen yang dapat diterangkan oleh model dalam persamaan ini adalah sebesar 0.924739 atau sebesar 9,2\%. Hal ini menunjukan bahwa Likuiditas(CR), Leverage (DER), Profitabilitas (ROA),Sales Growth (SG), Rasio Aktivitas (TATO) tidak mampu menjelaskan variasi naik/turunnya Financial distress karena hanya sebesar 9,2\% sedangkan sisanya sebesar 90,8\% dijelaskan oleh faktorfaktor lain selain Likuiditas(CR), Leverage (DER), Profitabilitas (ROA),Sales Growth $(S G)$, Rasio Aktivitas (TATO) yang tidak dimasukan dalam model regresi ini.

\section{Uji t (Parsial)}

\section{Pengaruh Likuiditas terhadap Financial Distress}

Nilai $t$-statistic Likuiditas (CR) dengan nilai sebesar 1.563402 lebih besar dari nilai t tabel sebesar 0.68156 dan nilai profitabilitas sebesar 0.1305 lebih besar dari 0,05 hal ini berarti bahwa variabel Likuiditas (CR) Tidak berpengaruh terhadap Financial Distress. Hasil ini sejalan dengan penelitian yang dilakukan oleh Simanjuntak, Titik, Aminah (2017), Nurcahyono, Sudharma (2014) menyatakan bahwa likuiditas tidak berpengaruh terhadap financial distress.

\section{Pengaruh Leverage terhadap Financial Distress}

Nilai $t$-statistic Leverage (DER) dengan nilai sebesar -2.155731 lebih kecil dari nilai t tabel sebesar 0.68156 dan nilai probalbilitas sebesar 0.0409 lebih kecil dari 0,05 hal ini berarti bahwa variabel leverage(DER) berpengaruh negative signifikan terhadap financial distress. Hasil ini sejalan dengan penelitian yang dilakukan oleh Simanjuntak, 
Titik, Aminah (2017), Rismawanti, Sukarmanto, Nurhayati (2017) menunjukkan bahwa leverage berpengaruh terhadap financial distress.

\section{Pengaruh Profitabilitas terhadap Financial Distress}

Nilai $t$-statistic Profitabilitas (ROA) dengan nilai sebesar 8.973539 lebih besar dari nilai t tabel sebesar 0.68156 dan nilai probalbilitas sebesar 0.0000 lebih kecil dari 0,05 hal ini berarti bahwa variabel profitabilitas(ROA) berpengaruh terhadap financial distress. Hasil ini sejalan dengan penelitian yang dilakukan oleh Hapsari (2012) yang menunjukan bahwa rasio profitabilitas berpengaruh terhadap financial distress.

\section{Pengaruh Sales Growth terhadap Financial Distress}

Nilai $t$-statistic Sales Growth (SG) dengan nilai sebesar -0.399757 lebih kecil dari nilai t tabel sebesar 0.68156 dan nilai probalbilitas sebesar 0.6927 lebih besar dari 0,05 hal ini berarti bahwa variabel sales growth (SG) tidak berpengaruh terhadap financial distress. Hasil ini sejalan dengan penelitian yang dilakukan oleh Simanjuntak, Titik, dan Aminah (2017) sales growth tidak berpengaruh terhadap financial distress.

\section{Pengaruh Rasio Aktivitas terhadap Financial Distress}

Nilai $t$-statistic Rasio Aktivitas (TATO) dengan nilai sebesar 1.422542 lebih besar dari nilai $\mathrm{t}$ tabel sebesar 0.68156 dan nilai probalbilitas sebesar 0.1672 lebih besar dari 0,05 hal ini berarti bahwa variabel rasio aktivitas (TATO) tidak berpengaruh terhadap financial distress. Hasil ini sejalan dengan penelitian yang dilakukan oleh Widhiari dan Merkusiwati (2015) yang menyatakan bahwa rasio aktivitas dengan proksi total asset turnover tidak berpengaruh terhadap financial distress.

\section{PENUTUP}

Berdasar hasil penelitian dan pembahasan yang telah dilaksanakan dapat disimpulkan yaitu Hasil pengujian secara parsial (uji t) menunjukkan bahwa; (1) Variabel Likuiditas yang dihitung dengan menggunakan rumus current ratio menunjukkan bahwa variabel likuiditas tidak berpengaruh terhadap financial distress; (2) Variabel Leverage yang dihitung dengan menggunakan rumus debt to total assets ratio menunjukkan bahwavariabel leverage berpengaruh terhadap financial distress; (3) Variabel Profitabilitas yang dihitung dengan menggunakan rumus return on assets menunjukkan bahwa variable profitabilitas berpengaruh terhadap financial distress; (4) Variabel Sales Growth menunjukkan bahwa variabel pertumbuhan penjualan tidak berpengaruh terhadap financial distress; (5) Variabel Rasio Aktivitas yang dihitung dengan menggunakan rumus total asset turnover menunjukkan bahwa variabel rasio aktivittas tidak berpengaruh terhadap financial distress.

Hasil pengujian secara simultan (uji f) membuktikan bahwa variabel Likuiditas, Leverage, Profitabilitas, Sales Growth, dan Rasio Aktivitas secara bersama-sama (simultan) berpengaruh terhadap Financial Distress perusahaan jasa sub sektor property, real estate, dan kontruksi bangunan yang terdaftar di BEI periode 2015-2018.

Berdasarkan kesimpulan yang telah dikemukakan, maka penelitian selanjutnya dapat menambah jumlah sampel dan tahun pengamatan penelitian. Variabel-variabel rasio keuangan yang lebih beragam, seperti return on asset, quick ratio, total asset turn over, return on equity, net profit margin, net profit growth, debt to equity ratio selain itu variabel independen lain yang diduga mempengaruhi financial distress, seperti ukuran perusahaan, dan mekanisme good corporate governance yang terdiri dari kepemilikan institusional, kepemilikan manajerial, komite audit, dan komisaris independen. Penelitian selanjutnya selain menggunakan data sekunder juga dapat menggunakan data 
primer dan dapat mengembangkan penelitian ini menjadi lebih luas agar penelitian dapat menggambarkan kondisi yang sebenarnya.

\section{DAFTAR PUSTAKA}

Asfali, Imam . Pengaruh Profitabilitas, Likuiditas, Leverage, Aktivitas, Pertumbuhann Penjualan Terhadap Financial Distress Perusahaan Kimia Imam Asfali. 20(2), $56-66$.

Vionita dan Lusmeida, Herlina. Analisis Pengaruh Kinerja Keuangan dan Good Corporate Governance Terhadap Financial Distress ( Studi Kasus Pada Perusahaan Manufaktur Yang Terdaftar di BEI 2014-2017 ).

Luh, N., Ayu, M., Lely, N. K., \& Merkusiwati, A. (2015). Pengaruh Rasio Likuiditas, Leverage, Operating Capacit, dan s Sales Growth terhadap Financial Distress. Fakultas Ekonomi dan Bisnis Universitas Udayana ( Unud ), Bali , vol 2, 456-469.

Perdana, N. S., \& Dillak, V. J. (2019). Pengaruh Rasio Likuiditas, Leverage, dan Sales Growth terhadp Financial Distress ( Studi Kasus pada Perusahaan Otomotif dan Komponen yang Terdaftar di Bursa Efek Indonesia Periode 20132016.vol 6(1), 668-674.

Simanjuntak, Christon, Farida Titik, dan Wiwin Aminah. 2017. Pengaruh Rasio Keuangan Terhadap Financial Distress Studi pada Perusahaan Transportasi yang Terdaftar di Bursa Efek Indonesia.E-Proceeding of Management, Vol. 4, No. 2, 1580-1587.

Rismawanti, Renty, Edi Sukarmanto, dan Nurhayati. 2017. Pengaruh Likuiditas, Sales Growth, dan Leverage Dalam Memprediksi Kondisi Financial Distress. Prosiding Akuntansi. Vol. 3, No.1, 1-7.

Bursa Efek Indonesia, Laporan keuangan tahun 2015, 2016, 2017, dan 2018. (diakses di http://www.idx.co.id)

Andre, Orina. 2013. Pengaruh Profitabilitas, Likuiditas, dan Laverage dalam Memprediksi Financial Distress (Studi Empiris Pada Perusahaan Aneka Industri Yang Terdaftar di BEI ). 